\title{
PROFESORU DAMIRU HORGI POVODOM SEDAMDESETOG ROĐENDANA
}

Dr. sc. Damir Horga rođen je 1938. godine u Zagrebu, gdje je završio osnovnu školu i gimnaziju. Na Filozofskom fakultetu u Zagrebu diplomirao je 1967. godine studijske grupe engleski jezik i književnost te ruski jezik i književnost. Godine 1974. završio je poslijediplomski studij fonetike obranivši magistarski rad pod naslovom Faktori koji strukturiraju visinsku optimalu riječi. Disertaciju pod naslovom Sposobnosti procesiranja fonetskih informacija obranio je 1987. godine.

Prije završetka studija, a nakon diplomiranja ruskog kao B predmeta, od 1963. do 1965. godine predavao je ruski jezik u školi za prevoditelje u Monsu (Belgija), kamo ga je uputio Zavod za fonetiku Filozofskog fakulteta u Zagrebu, budući da je već tada kao student bio član-volonter Zavoda za fonetiku. Godine 1966. postao je stručni suradnik Zavoda za fonetiku Filozofskog fakulteta u Zagrebu. Na toj dužnosti ostao je do 1979. godine, kada je izabran za asistenta na Odsjeku za teorijsku i primijenjenu fonetiku. U listopadu iste godine izabran je za znanstvenog asistenta. Godine 1987. izabran je u zvanje znanstvenog suradnika, 1988. postao je docent, 1989. izvanredni profesor, 1996. redoviti profesor, a u trajno znanstvenonastavno zvanje redovitog profesora izabran je u srpnju 2001. godine.

Usavršavao se u Moskvi i Lenjingradu, a 1998. dio slobodne studijske godine proveo je na UCLA-u u Los Angelesu. Vodio je seminare o AVGS metodi u zemlji i inozemstvu (Belgija, Mađarska i Italija) i održao pozvana predavanja na sveučilištima u Ljubljani (Slovenija), te Torunju i Varšavi (Poljska).

U sklopu djelatnosti Zavoda i Odsjeka za fonetiku radio je na brojnim istraživačkim projektima; bio je voditelj projekta Ministarstva znanosti Hrvatske Metodologija istraživanja jezika struke u visokoškolskoj nastavi, glavni istraživač na projektima Pragmalingvistika prirodnih jezika i Artikulacijski i neurolingvistički opis proizvodnje govora, a do umirovljenja bio je glavni istraživač na projektu Ministarstva znanosti, obrazovanja i športa Proizvodnja i percepcija govora (već u drugom projektnom razdoblju od 2002). U tim projektima koordinirao je rad brojnih suradnika s Odsjeka za fonetiku, ali i s drugih odsjeka, odnosno centara Filozofskog fakulteta, Medicinskog fakulteta i Edukacijsko-rehabilitacijskog fakulteta, a priliku za znanstveno-istraživački rad i razvoj dobilo je troje izvrsnih mladih profesora fonetike zaposlenih kao novaci. Svojom je znanstvenom znatiželjom, neposrednošću i kooperativnošću, a ponajviše otvorenošću za nove ideje i pristupe, uspijevao izvući najbolje od svih.

Impresivan je i Horgin sažetak objavljenih radova i javnih nastupa, kao i njegova znanstvena aktivnost općenito. Autor je jedne znanstvene knjige, a samostalno ili u koautorstvu objavio je šest udžbenika, devet poglavlja u knjigama, 93 znanstvena rada (četiri u CC časopisima, 42 rada citirana u drugim sekundarnim publikacijama, 14 u ostalim časopisima, 16 u zbornicima s međunarodnih skupova i 17 u zbornicima s domaćih skupova), dvadesetak stručnih radova i prikaza, te 47 
sažetaka u zbornicima. Sudjelovao je u izradi obrazovnih emisija Radio Zagreba kao autor 60 polusatnih emisija ruskog jezika. Izložio je devedesetak radova na međunarodnim i domaćim znanstvenim i stručnim skupovima. Uredio je samostalno ili kao kourednik četiri znanstvena zbornika. Recenzirao je četiri znanstvene knjige i brojne članke. Sudjelovao je u organizaciji desetak znanstvenih i stručnih skupova kao predsjednik ili član programskih i organizacijskih odbora.

Tijekom više od 40 godina bavljenja fonetikom i lingvistikom Damir Horga ogledao se u svim područjima tih disciplina, ali se njegov rad koncentrira na nekoliko glavnih pravaca. To je prvenstveno proizvodnja govora sa svim njezinim vidovima - od neurofizioloških načela, preko artikulacijskih opisa, mjerenja govornih sposobnosti, fluentnosti i govornih pogrešaka, do različitih poremećaja. U primijenjenoj fonetici i lingvistici najzapaženije je njegovo bavljenje učenjem stranih jezika i s time povezanim izgovornim pogreškama. Njegovih ukupno stotinjak objavljenih radova odražava tu raznolikost. Značajka je svih Horginih radova dobra teorijska utemeljenost sa širokim uvidom u prethodna istraživanja drugih autora u svijetu, dobro postavljen eksperiment, veliki uzorci i točnost mjerenja, te korektne metode statističkih obrada podataka. Sve to svrstava ga među ponajbolje znanstvenike i stručnjake, ne samo u Hrvatskoj nego i u inozemstvu.

U knjizi Obrada fonetskih obavijesti (Hrvatsko filološko društvo, 1996) obrađuje temeljnu fonetsku problematiku s psihološkog i neurološkog stajališta, posebice problem invarijantnosti govornih signala, problem (ne)autonomnosti govora $u$ psihoneurološkom pogledu, adaptacijske mehanizme is tim u vezi sustave kontrole i povratnih sprega, problem hemisferalnih podjela u obradi govora, problem razina (psiholoških i neuroloških) pri obradi govora, načine proizvodnje i načine percepcije govora u neuropsihološkim slojevima i, za ovu knjigu najvažnije, međusobnu uvjetovanost percepcije i proizvodnje. Iz brojnih mjernih podataka prikupljenih na velikom broju ispitanika tijekom više godina, prikladnim instrumentarijem i metodama obrade autor dolazi do novih čvrstih spoznaja koje se odnose na problem veze percepcije i proizvodnje govora. Knjiga možda najbolje sažima i otkriva širinu svih Horginih interesa, i to na način pristupačan kako studentima fonetike i srodnih disciplina tako i laicima.

Za fonetski opis hrvatskog jezika u svjetskim razmjerima vjerojatno je najveći Horgin doprinos koautorstvo obujmom nevelikog, ali važnog članka/poglavlja Croatian u knjizi Handbook of the International Phonetic Association (London: Cambridge University Press, 2000), u kojem se u urednički zadanim okvirima koncizno i zaokruženo hrvatski smješta među desetke jezika svijeta čiji se opisi nalaze u toj zbirci koja je nezaobilazno štivo svih fonetičara u svijetu.

Ukupan znanstveni doprinos Damira Horge možda je najbolje sažeo profesor Ivo Škarić u obrazloženju prijedloga za izbor u trajno zvanje: "Iz nekoliko ovdje lapidarno opisanih istraživanja dade se, vjerujemo, naslutiti koliko je duboko Horga pronikao u bit govora. Dojam je da je stigao do samog do sada otkrivenoga dna, odakle kao da jasno vidi kako potpuno spoznavanje govora seže do bezdana. 
Svjestan je na koliko se sve strana otvaraju pitanja i kao da mu se žuri odgovoriti na što više postavljenih zagonetaka. Zato živi sa svojim istraživanjima potpuno - u isti mah grozničavo i staloženo, jer želi što više toga otkriti i biti što sigurniji da je to, što se pričinja da jest, i jest to. Fonetska znanost, naša i svjetska, mnogo je dobila i danomice dobiva od toga što Damir Horga u njoj tako predano i kreativno djeluje."

$S$ podjednakim žarom kojim se bavi fonetskom znanošću, Horga se predaje i nastavničkom i mentorskom radu. U svim anketama, kako službenima tako i onima neformalnima koje se mogu pronaći na različitim forumima za razmjenu studentskih mišljenja, dobiva najbolje ocjene, a ono što studenti najviše cijene jesu njegova dostupnost, neposrednost i spremnost da pomogne. To su prepoznali ne samo studenti Filozofskog fakulteta svih razina, od brucoša do doktoranada, nego i studenti Edukacijsko-rehabilitacijskoga fakulteta na kojem je godinama predavao fonetiku, polaznici VT seminara u organizaciji Poliklinike za rehabilitaciju slušanja i govora SUVAG, ali i generacije darovitih srednjoškolaca s kojima 18 godina dolazi u kontakt kao predavač na Govorničkoj školi od njezina osnutka.

Tijekom svog rada na Filozofskom fakultetu osmislio je mnoge nove kolegije u skladu sa svjetskim trendovima u razvoju fonetske znanosti i struke te svojim interesima (primjerice Neurofonetika), a istodobno konstantno razvijao one za fonetičara temeljne i nezaobilazne, kao što je Artikulacijska fonetika. Svoju je nastavu obogatio suradnjom s kolegicama i kolegama različitih struka (npr. medicine, stomatologije, neuroznanosti), a sve u nastojanju da tu nastavu učini što dinamičnijom, zanimljivijom i aktualnijom. Brojna mentorstva i članstva u povjerenstvima za ocjenu i obranu završnih radova različitih razina, od diplomskih do doktorskih, kako na Filozofskom fakultetu tako i izvan njega, još su jedan dokaz povjerenja koje Damir Horga uživa među studentima, ali i kolegama i kolegicama.

Član je domaćih i međunarodnih stručnih udruga iz fonetike i primijenjene lingvistike. Od 1987. do 1989. obnašao je funkciju predsjednika Hrvatskog društva za primijenjenu lingvistiku, a predsjednika Odjela za fonetiku Hrvatskog filološkog društva od 1993. do 2001. U tih osam godina znatno je pridonio oživljavanju rada Odjela za fonetiku. Nakon dulje stanke obnovljen je i proširen popis članstva i potaknute brojne aktivnosti. Odjel se počeo redovito sastajati jednom mjesečno ugošćujući brojne goste-predavače iz različitih područja fonetike i srodnih disciplina, a posebna je vrijednost poticanje studenata viših godina fonetike na dolaske i sudjelovanje u raspravama. Sva su predavanja bila izvrsno posjećena, a ta se aktivnost održala sve do danas. Bez dvojbe, tome je pridonio Horgin osobni angažman i nastojanje da fonetiku približi što širem krugu kolegica i kolega, ali i da mnoge srodne znanosti približi fonetičarima.

Od 1988. godine član je uredništva časopisa Govor, a od 2003. do 2010. godine bio je njegov glavni urednik. Od 1992. do 1996. bio je glavni urednik časopisa Strani jezici. Dok je bio na čelu uredništava obaju časopisa, znatno je pridonio njihovoj kvaliteti i čitanosti u znanstvenim i stručnim krugovima. Za časopis Govor posebice je važno da je proširio citiranost na devet baza, za što je najviše zaslužna redovitost 
izlaženja i vrsnoća objavljenih članaka, opet rezultat zalaganja upravo glavnoga urednika. Tu je vrsnoću priznala i hrvatska znanstvena zajednica priznajući konačno Govoru status časopisa izjednačen s međunarodnima.

Na Filozofskom fakultetu obnašao je funkcije predsjednika poslovodnog kolegija od 1983. do 1984. i od 1989. do 1991, pročelnika Odsjeka za fonetiku u nekoliko mandata. Od 2003. do umirovljenja 2009. godine bio je predstojnik Katedre za teorijsku fonetiku Odsjeka za fonetiku. Osim toga, član je Povjerenstva za sport Sveučilišta u Zagrebu, od 2005. godine član je Povjerenstva za akademsko priznavanje inozemnih visokoškolskih kvalifikacija, a od 2004. do 2008. godine bio je član Matičnog povjerenstva za područje humanističkih znanosti, polje filologija, Ministarstva znanosti, obrazovanja i športa Republike Hrvatske.

U mirovinu je otišao 2009. godine kada je i dobio Povelju Filozofskog fakulteta koja je po svom karakteru zapravo nagrada za životno djelo zaslužnim profesorima. A zaslužan je Horga doista za razvoj fonetske znanosti, za kvalitetu nastave i istraživanja na Odsjeku za fonetiku Filozofskog fakulteta, za mnoge izvrsne diplomske radove i stručnjake koji su imali sreću formirati se pod njegovim mentorstvom. Uvijek prisutan, ali nikad agresivan u nastupu, rijetko dovoljno glasan da se istakne, ali uvijek jedan od najvrjednijih i gotovo nezamjenjivih članova svakog tima, spreman na pomoć, ali nenametljiv, pun ideja i inicijativa, ali uvijek prezentiranih kao da su zajedničke. To su neke od glavnih odlika koje Horgu čine omiljenim sugovornikom i suradnikom u svim krugovima - znanstvenim, stručnim, ali i prijateljskim, kako među kolegama i prijateljima tako i među studentima.

Vesna Mildner i Marko Liker 